\title{
Strategi Pemasaran Produk PRULink Syariah Assurance Account Pada PT. Prudental Life Assurance Cabang Kota Malang
}

\author{
Ernawati \& Moch. Novi Rifa'i \\ Program Studi Ekonomi Syariah, \\ Fakultas Agama Islam, Universitas Muhammadiyah Malang \\ E-mail: ernawatilove68@gmail.com
}

\begin{abstract}
This study aims to determine what marketing strategy implemented by PT. Prudential Life Assurance Malang City Branch in marketing PRUlink Syariah Assurance Account. Selection of PT. Prudential Life Assurance Malang Branch as a place of research is based on developments on the world of insurance, and PT. Prudential Life Assurance Malang Branch is one of the fastest growing insurance companies. This research uses descriptive research with qualitative approach, that is researcher analyze data based on information obtained from interview result, observation, and other source. While for data analysis using qualitative analysis. From the results of this study can be concluded that the marketing strategy implemented by PT. Prudential Life Assurance Malang Branch On PRUlink Syariah Product Assurance Account is using internal marketing strategy that is strategy conducted by company related to the company itself and external marketing strategy that is indirect influence where is outside of power or control of marketer.
\end{abstract}

Keywords: Strategy, marketing, PRUlink Syariah Assurance Account, PT. Prudential Life Asssurance.

\section{Pendahuluan}

Asuransi sebagai salah satu lembaga keuangan yang bergerak dalam bidang pertanggungan merupakan sebuah institusi modern hasil temuan dari dunia barat yang lahir bersamaan dengan adanya semangat pencerahan. Institusi ini bersama dengan lembaga keuangan bank menjadi motor penggerak ekonomi pada modern dan berlanjut pada masa kini. Dasar yang menjadi semangat operasional asuransi modern adalah berorientasikan pada sistem kapitalis yang intinya hanya bermain dengan pengumpulan modal untuk keperluan pribadi atau golongan tertentu. Lain 
hal nya dengan asuransi syariah. Asuransi dalam literature keislaman lebih banyak bernuansa sosial dari pada ekonomi atau profit oriented (keuntungan bisnis). Hal ini dikarenakan adanya aspek dan tolong menolong yang menjadi dasar utama dalam menegakkan praktik asuransi dalam islam. ${ }^{1}$

Konsep dasar asuransi syariah adalah tolong menolong dalam kebaikan dan ketakwaan (al birri wa taqwa). Konsep tersebut sebagai landasan yang diterapkan dalam setiap perjanjian transaksi bisnis dalam wujud tolong menolong (akad takaful) yang menjadikan semua peserta sebagai keluarga besar yang saling menanggung satu sama lain dalam resiko, sebagaimana firman allah SWT yang memerintahkan kepada kita untuk taawun (tolong menolong) yang berbentuk al birri wa taqwa (kebaikan dan ketaqwaan) dan melarang taawun dalam bentuk al itsmi wal udwan (dosa dan permusuhan). Dalam asuransi konvensional, asuransi merupakan pemindahan resiko dari peserta atau tertanggung ke perusahaan / penanggung. Sebagai konsekuensi maka kepemilikan dana berpindah, dana peserta menjadi milik perusahaan asuransi. Perbedaan yang paling utama diantara keduanya asuransi syariah dan asuransi konvensional terletak pada pengelolaan dan pendayagunaan premi yang disetor peserta, serta sumber dan cara pembayaran klaim. ${ }^{2}$

Mengenali karakteristik pasar dan struktur pasar sangatlah menguntungkan bagi perusahaan agar dapat tetap bersaing dan bertahan. Kelemahan dan keunggulan perusahaan hendaknya dianalisis sehingga menjadi sebuah titik tolak ukur yang kuat untuk perusahaan dalam mengambil keputusan yang efektif dan efesien serta untuk memperkuat posisi dari pesaing yang ada. Untuk mempertahankan kelangsungan hidupnya, dalam berkembang dan memperoleh keuntungan, perusahaan harus melakukan salah satu fungsi pokoknya yaitu pemasaran. Sedangkan pemasaran terdiri dari atas serangkaian prinsip untuk memilih pasar sasaran (Target Market), mengevaluasi kebutuhan konsumen, mengembangkan barang dan jasa pemuas keinginan, memberi nilai kepada konsumen dan laba perusahaan. ${ }^{3}$ Pemasaran adalah fungsi yang memiliki kontak paling besar dengan lingkungan eksternal, perusahaan hanya memiliki kendali yang terbatas terhadap lingkungan eksternal. Oleh karena itu, pemasaran memainkan peran penting dalam pengembangan strategi. ${ }^{4}$ Strategi pemasaran pada dasarnya adalah rencana yang menyeluruh, terpadu dan menyatu dibidang pemasaran, yang memberikan panduan tentang kegiatan yang akan dijalankan untuk dapat tercapainya tujuan pemasaran suatu perusahaan. ${ }^{5}$

\footnotetext{
1 Hasan Ali, Asuransi Dalam Prespektif Hukum Islam Suatu Tujuan, Teori dan Praktis (Jakarta: Kencana, 2004), hal. 55.

${ }^{2}$ Yadi Janwari, Asuransi Syariah (Bandung: Pustaka Bani Quraisy, 2005), hal. 5

${ }^{3}$ Murti Sumiarti, John Soepriharto Pengantar Bisnis (Yogyakarta: Liberty, 2000), hal. 262.

${ }^{4}$ Fandy Tjiptono, Strategi Pemasaran (Ed. 3 Yogyakarta: Andi,2008), hal. 5.

${ }^{5}$ Ibid, hal. 168.
} 


\section{Strategi dan Bauran Pemasaran}

Menurut Tjiptono, strategi pemasaran adalah pernyataan (baik secara emplisit maupun akplisit) mengenai bagaimana suatu merk atau lini produk mencapai tujuannya. Strategi pemasaran sebagai alat fundamental yang direncanakan untuk mencapai tujuan perusahaan dengan mengembangkan keunggulan bersaing dan berkesinambungan melalui pasar yang dimasuki dan program pemasaran yang digunakan untuk melayani pasar sasaran tersebut. ${ }^{6}$ Menurut sofjan Assauri strategi pemasaran adalah rencana yang menyeluruh, terpadu, dan menyatu dibidang pemasaran. Yang memberikan panduan tentang kegiatan yang akan dijalankan untuk dapat tercapainya tujuan pemasaran suatu perusahaan, dengan kata lain pemasaran adalah serangkaian sasaran dan tujuan. Kebijakan dan aturan yang memberi arah usaha-usaha pemasaran dari waktu kewaktu, pada masingmasing tingkatan dan acuan serta lokasi, terutama sebagai tanggapan perusahaan dalam menghadapi lingkungan dan keaadaan persaingan yang berubah-ubah. ${ }^{7}$

Dalam Islam, tidak ada larangan bila seorang hamba memiliki rencana atau keinginan untuk memperjuangkan usahanya agar berhasil. Dengan syarat, rencana tersebut tidak bertentangan ajaran islam, sebagaimana firman Allah Swt, dalam surat An-Najm ayat 24-25 :

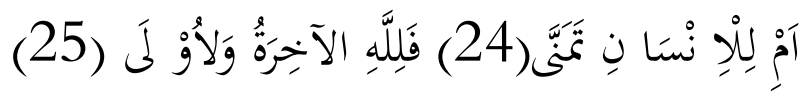

Artinya: Atau apakah manusia akan mendapatkan segala yang dicita-citakannya? (Tidak) maka hanya bagi Allah kehidupan akhirat dan kehidupan dunia. (QS. An Najm 24-25)

Bila dikaitkan dengan ayat tersebut, strategi pemasaran merupakan suatu upaya yang dilakukan untuk menciptakan atau mencapai sasaran pemasaran sesuai dengan harapan dalam mencapai keberhasilan. Sudah menjadi sunatullah bahwa segala sesuatu yang direncanakan oleh manusia berhasil atau tidak, bahwa semua ketentuan dari Allah Swt. Dalam islam, pelaksanaan suatu perencanaan harus bergerak kearah sintesis yang wajar antara pertumbuhan ekonomi dan keadilan sosial. Pelaksanaan perencanaan harus dilakukan melalui penetapan kebijakan yang tetap konsisten dengan jiwa islami yang tidak terlepas dari tuntutan Alqur'an dan Hadis, serta sesuai dengan kode etik ekonomi Islam. ${ }^{8}$

Marketing Mix merupakan kombinasi variabel atau kegiatan inti dari sistem pemasran, variabel yang dapat dikendalikan oleh perusahaan untuk mempengaruhi reaksi para pembeli atau konsumen. Jadi Marketing Mix terdiri

\footnotetext{
${ }^{6}$ Fandy Tjiptono, Strategi Pemasaran (Yogyakarta: ANDI , 2008), hal. 6.

7 Sofjan Assuri, Manajemen perusahaan (Cet .7. Ed. 1; Jakarta: PT. Raja Grafindo Persada, 2004), hal. 168.

${ }^{8}$ Veithzal Rifai Zainal, et al., Islamic Marketing Management (Jakarta: PT. Bumi Aksara 2017), hal. 81 .
} 
dari himpunan variabel yang dapat dikendalikan dan digunakan oleh perusahaan untuk mempengaruhi tanggapan konsumen dalam pasar sasarannya. Variabel atau kegiatannya tersebut perlu dikombinasikan dan dikoordinasikan oleh perusahaan seefektif mungkin dalam kegiatan pemasarannya. Dengan demikian, perusahaan tidak hanya sekedar memiliki kombinasi kegiatan yang terbaik saja, akan tetapi dapat mengkoordinasikan berbagai kegiatan marketing mix tersebut untuk melaksanakan program pemasaran secara efektif. ${ }^{9}$ Dalam strategi pemasaran, terdapat bauran pemasaran (marketing mix), yang menetapkan komposisi terbaik dari kelima komponen atau variabel pemasaran, untuk dapat mencapai sasaran pasar yang dituju sekaligus mencapai tujuan dan sasaran perusahaan. Kelima unsur variabel tersebut terdiri dari produk (product), harga (price), tempat (place), promosi (promotion) dan orang (people). ${ }^{10}$

\subsection{Produk (Product)}

Produk adalah segala sesuatu yang dapat ditawarkan kepada pasar untuk mendapat perhatian, dimiliki digunakan atau dikonsumsi, yang meliputi barang secara fisik, jasa, kepribadian, tempat, organisasi dan gagasan atau buah fikiran. ${ }^{11}$ Tujuan utama strategi produk adalah untuk dapat mencapai sasaran pasar yang dituju dan meningkatkan kemampuan bersaing atau mengatasi persaingan. Oleh karena itu, strategi produk sebenarnya merupakan strataegi pemasaran, sehingga gagasan atau ide untuk melaksankannya harus datang dari bagian atau bidang pemasaran. Faktor -faktor yang jterkandung dalam suatu produk adalah mutu atau kualitas, penampilan (features), pilihan yang ada (option), gaya (styles), merek (brand names), pengemasan (packing), ukuran (size), jenis (product lines), macam (product item), jaminan (warranties), dan pelayanan (service). ${ }^{12}$

\subsection{Harga (Price)}

Harga (price) adalah jumlah yang ditagihkan atas suatu produk atau jasa. Harga adalah jumlah semua nilai yang diberikan oleh pelanggan untuk mendapatkan keuntungan dari memiliki atau menggunakan suatu produk atau jasa. ${ }^{13}$ Pada setiap produk dan jasa yang ditawarkan, bagian pemasaran berhak menentukan harga produknya, faktor-faktor yang perlu dipertimbangkan dalam penetapan harga adalah: biaya, keuntngan, praktek saingan dan perubahan keinginan pasar. Kebijakan harga ini menyangkut pula penetapan jumlah potongan dan sebagainya yang berhubungan dengan harga. Hendaknya setiap perusahaan dapat menetapkan harga yang paling tepat yang dapat memberikan keuntungan yang paling baik, baik dalam jangka pendek maupun jangka panjang.

\footnotetext{
${ }^{9}$ Ibid, hal. 198.

${ }^{10}$ Ibid, hal. 199.

11 Sofjan Assauri, Manajemen Pemasaran Dasar, Konsep dan Strategi (Jakarta: Raja Grafindo Persada, 2009), hal. 200.

12 Ibid, hal. 200.

13 Veithzal Rifai Zainal, et al., Islamic Marketing Management (Jakarta: PT. Bumi Aksara, 2017), hal. 423.
} 


\subsection{Tempat (Place)}

Tempat dalam pemasaran dapat diartikan sebagai proses distribusi atau penyaluran. Distribusi adalah kegiatan pemasaran yang berusaha memperlancar dan mempermudah penyampaian barang dan jasa dari produsen, sehingga penggunaannya sesuai dengan yang diperlukan (jenis, jumlah, harga dan tempat saat dibutuhkan). ${ }^{14}$

\subsection{Promosi (Promotion)}

Promosi merupakan salah satu faktor penentu keberhasilan suatu program pemasaran. Pada hakikatnya promosi adalah suatu bentuk komunikasi pemasaran, yang mana komunikasi pemasaran adalah aktivitas pemasaran yang berusaha menyebarkan informasi, mempengaruhi/membujuk atau mengingatkan pasar sasaran atas perusahaan dan produknya agar produknya bersedia menerima, membeli, dan loyal pada produk yang ditawarkan perusahaan yang bersangkutan. ${ }^{15}$ Kegiatan promosi yang dilakukan oleh perusahaan menggunakan acuan/bauran promosi (promotional mix) yang terdiri atas periklanan (Advertensi), personal selling, promosi penjualan (sales promotion) dan publikasi (publicity). ${ }^{16}$

\subsection{Orang (People)}

Bagi sebagian besar jasa, orang merupakan unsur vital dalam bauran pemasaran. Orang berfungsi sebagai penyedia jasa sangat mempengaruhi kualitas jasa yang diberikan. Untuk mencapai kuallitas diperlukan pelatihan staf sehingga karyawan mampu memberikan kepuasan kepada konsumen. ${ }^{17}$

\section{Asuransi Syariah, Produk PRUlink Syariah Assurance Account}

\subsection{Asuransi Syariah}

Dewan Syariah Nasional Majelis Ulama Indonesia (DSN-MUI) dalam fatwanya menjelaskan tentang definisi asuransi syariah (Ta'min,Takaful atau Tadamun ) adalah usaha saling melindungi dan tolong menong diantara sejumlah orang atau pihak melalui investasi dalam bentuk asset dan atau tabarru' yang memberikan pola pengembalian untuk menghadapi resiko tertentu melalui akad (perikatan) yang sesuai dengan prinsip syariah.

Didalam al-qur'an telah dijelasakan tentang konsep asuransi dan mempunyai muatan nilai -nilai asuransi, seperti tolong menolong atau menghilangkan kesukaran sesama manusia. Seperti firman Allah QS. AlMaidah[4]: 2 yang berbunyi :

\footnotetext{
14 Fandy Tjiptono, Strategi Pemasaran (Ed.3 Yogyakarta: Andi, 2008), hal. 185.

15 Ibid., hal. 219.

16 Sofjan Assauri, Manajemen Pemasaran Dasar, Konsep dan Strategi (Jakarta: Raja Grafindo Persada, 2009), hal. 269.

17 Fandy Tjiptono, Pemasaran Jasa (prinsip,penerapan dan penelitian) (Yogyakarta: ANDI, 2014), hal. 42.
} 


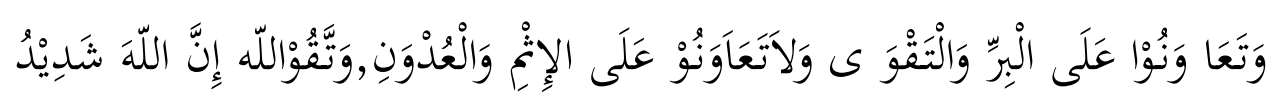

$$
\begin{aligned}
& \text { الْعَقَا بَ }
\end{aligned}
$$

Artinya: "Dan tolong-menolonglah kamu dalam (mengerjakan) dalam hal kebajikan dan taqwa, jangan tolong menolong dalam berbuat dosa dan pelanggaran, dan bertaqwalah kamu kepada Allah, Sesungguhnya Allah amat berat siksa-Nya"

\subsection{Produk PRU link Syariah Assurance Account}

PRUlink Syariah Assurance Account adalah produk asuransi jiwa yang dikaitkan dengan investasi yang memberikan perlindungan sekaligus keuntungan berinvestasi yang sesuai dengan prinsip - prinsip syariah.

Keistimewaan dari produk PRUlink Syariah Assurance Account yaitu:

a) Manfaat kematian.

b) Manfaat cacat total dan tetap.

c) Dapat menambah uang pertanggungan setiap saat.

d) Dapat melakukan penambahan kontribusi setiap saat.

e) Dapat menentukan sendiri besarnya komposisi dari nilai proteksi dan nilai investasi.

f) Dapat melakukan pegalihan dana.

g) Pilihan manfaat asuransi tambahan yang beragam.

h) Surplus Sharing dana yang akan diberikan kepada pemegang polis bila terdapat kelebihan dari rekening tabarru'.

Untuk persyaratan usia masuk pada PRUlink Syariah Assurance Account adalah:

a) Pemegang polis minimal 21 tahun

b) Peserta $1-70$ tahun.

c) Adapun manfaat dari produk PRUlink Syariah Assurance Account yaitu,

d) Memberikan perlindungan jiwa seumur hidup hingga berusia 99 tahun,

e) Memberikan perlindungan cacat total dan tetap hingga usia 70 tahun.

\section{Strategi Pemasaran Produk PRUlink Syariah Assurance Account}

Berdasarkan hasil wawancara dengan Pimpinan PT. Prudential Life Asssurance Cabang Kota Malang Bapak Nuzulkifli, strategi pemasaran yang digunakan oleh PT. Prudential Life Assrance Cabang Kota Malang terkait dengan strategi pemasaran produk PRULink Syariah Assurance Account, terdapat dua strategi untuk menghadapi persaingan yaitu strategi pemasaran internal dan strategi pemasaran eksternal. Dua strategi ini dilakukan karena untuk memaksimalkan daya tarik produk yang di harapkan mampu di terima oleh masyarakat.

\subsection{Strategi Pemasaran Internal}

Stretegi pemasaran internal yaitu tugas merekrut, melatih, dan memotivasi karyawan - karyawan yang kompeten, yang ingi melayani pelanggan dengan baik. Pemasar yang cerdas menyadari bahwa aktivitas pemasar di dalam perusahaan bisa menjadi sepenting atau bahkan lebih penting daripada aktivitas pemasar yang diarahkan keluar perusahaan. Tidak masuk akal menjanjikan pelayanan yang 
prima sebelum staff perusahaan siap memberikannya. ${ }^{18}$ PT. Prudential Life Assurance Cabang Kota Malang terlebih dahulu menentukan target pasar sesuai dengan produk yang akan di tawarkan kepada para calon nasabahnya. Dalam hal ini PT. Prudential Life Assurance Cabang Kota Malang dalam mengambil keputusan memperhatikan komponen- komponen bauran Pemasaran (marketing mix), yang terdiri dari 5P yaitu Produk, Harga, Promosi, Tempat,dan Orang.

\section{1) Produk (Product)}

Penetapan produk pada PT. Prudential Life Assurance Cabang Kota Malang harus menarik nasabah. Untuk itu PT. Prudential Life Assurance Cabang Kota Malang mempunyai straegi dalam menetapkan produk, diantaranya: ${ }^{19}$

\section{a) Keragaman Produk}

PT. Prudential Life Assurance Cabang Kota Malang mempunyai beberap produk asuransi seperti PRUlink Investor account, PRUlink assurance account, PRUlink syariah assurance account, PRUlink syariah investor account, dan PRUmy child. Dengan adanya produk asuransi tersebut nasabah dapat memilih jenis asuransi dan investasi apa yang akan dipilih.

\section{b) Kualitas Produk}

PT. Prudential Life Assurance Cabang Kota Malang berusaha membuat mutu yang ada pada setiap produk asuransi yang mampu bersaing. Karena PT. Prudential Life Assuurance Cabang Kota Malang bergerak di bidang jasa. Jadi tolak ukur dari kualitas suatu produk adalah pelayanan atau tanggapan, keluhan, dan sikap konsumen terhadap pelayanan suatu produk. Selama ini tidak ada keluhan nasabah terbukti dengan peningkattan jumlah nasabah pada tiap bulannya.

\section{c) Ciri Produk}

Produk harus mempunyai ciri yang menonjol agar konsumen tertarik. Misalnya pada produk PRUlink Syariah Assurance Account yang menggunakan akad Tijarah atau disebut dengan wakalah bil ujrah.

\section{d) Merek Produk}

PT. Prudential Life Assurance Cabang Kota Malang memberikan suatu nama produknya berbeda dengan nama produk perusahaan asuransi lainnya. Dengan nama yang khas, dan mudah dipahami PT. Prudential Life Asssurance Cabang Kota Malang dapat menarik nasabah.

\section{e) Keistimewaan Produk}

\footnotetext{
${ }^{18}$ Philip Kotler, Manajemen Pemasaran Edisi 13, (PT. Gelora Aksara Pratama), 2008.

${ }^{19}$ Wawancara dengan Bapak Nuzulkifli (pimpinan), tanggal 07 Juni 2017
} 
Agar nasabah dapat tertarik pada produk PRUlink Syariah Assurance Account, maka PT. Prudential Life assurance Cabang Kota Malang memberikan keistimewaan pada produknya. Selain itu, pada produk PRUlink Syariah Assurance Account Ini juga memberikan manfaat untuk nasabah yang menggunakan produk ini, diantaranya:

a) Manfaat Kematian (Death Benefit)

b) Manfaat cacat total dan tetap (Total and Parment)

c) Dapat menambahkan nilai uang pertanggungan (Sum Assured) setiap saat.

d) Dapat menentukan sendiri besarnya komposisi dari nilai proteksi dan nilai investasi

e) Dapat melakukan pengalihan dana (Fund Switching)

f) Pilihan manfaat asuransi tambahan (Riders) yang beragam

g) Surplus Sharing, dana yang akan diberikan kepada pemegang polis bila terdapat kelebihan dana dari rekening Tabarru'.

\section{2) Harga (Price)}

Yang di maksud harga pada perusahaan asuransi adalah biaya premi. PT. Prudential Life Assurance Cabang Kota Malang khususnya pada Produk PRUlink Syariah Assurance Account. Biaya premi minimum yaitu Rp. 400.000 dan maximum Unlimited atau tidak terbatas. Usia, jenis pekerjaan dan status merokok juga mempengaruhi nilai biaya premi, dengan semakin tinggi usia seseorang, maka biaya premi asuransi akan semakin mahal. Menurut Bapak Bambang harga yang diberikan oleh PT. Prudential Life Assurance Cabang Kota Malang sudah mengikuti pasaran dengan perusahaan asauransi lainnya. ${ }^{20}$

\section{3) Tempat (Place)}

PT. Prudential Life Assurance Cabang Kota Malang terletak di Jl. Kedawung No. 67, Tulusrejo, Kec. Lowokwaru Kota Malang, Jawa Timur. Lokasi PT. Prudential Life Assurance Cabang Kota Malang Sangat Strategis karena letaknya yang dipinggir jalan sehingga masyarakat banyak yang tahu tentang keberadaan PT. Prudential Life Assurance Cabang Kota Malang.

\section{4) Promosi (Promotion)}

Untuk memperkenalkan produk dan sebagai usaha mengoptimalkan pemasaran PT. Prudential Life Assurance Cabang Kota Malang mempunyai strategi promosi sebagai berikut: ${ }^{21}$

\footnotetext{
${ }^{20}$ Wawancara dengan Bapak Bambang (Agen), tanggal 02 Agustus 2017

${ }^{21}$ Wawancara dengan Bapak Nuzulkifli, tanggal 07 Juni 2017
} 


\section{a). Periklanan}

Dalam promosi periklanan oleh PT. Prudential Life Assurance Cabang Kota Malang yaitu menggunakan media cetak atau elektronik seperti iklan di televisi, pemasangan spanduk, papan rekalame, brosur dan koran. Dalam mengiklankan produknya PT. Prudential Life Assurance Cabang Kota Malang lebih menonjolkan keistimewaan produk dan keuntungan lainnya.

\section{b). Personal Selling}

PT. Prudential Life Assurance Cabang Kota Malang memfokuskan melakukan promosi dengan cara Personal Selling untuk meningkatkan promosi. Yaitu Para pemasar (pemasar) menjual langsung kepada individu - individu langsung. Karena dengan promosi personal selling maka para pemasar dapat bertatap muka langsung dengan para nasabah ataupun calon nasabah.

\section{5) Orang (People)}

PT. Prudential Life Assurance Cabang Kota Malang memberikan pelayanan tentang produk - produk PT. Prudential Life Assurance Cabang Kota Malang kepada pelanggan dengan melalui telephone, E-mail, dan juga dapat mengakses websitenya yang dapat di akses dengan mudah serta bisa bertemu secara langsung dengan nasabah. disamping itu, pelayanan oleh PT. Prudential Life Assurance cabang Kota Malang dengan ramah, sopan dan rapi. Salah satu kunci yang paling penting untuk menjaga kualitas kinerja PT. Prudential Life Assurance Cabang Kota Malang adalah mengembangkan dan mendidik karyawannya secara berkesinambungan. PT. Prudential Life Assurance Cabang Kota Malang memiliki komitmen yang tinggi terhadap peningkatan kualitas sumber daya manusia (SDM). SDM yang unggul adalah penopang utama untuk menjadi pemimpin pasar dan pengembangan asuransi. Untuk melahirkan SDM yang unggul, PT. Prudential Life Assurance Cabang Kota Malang menumbuhkembangkan budaya pembelajaran serta berkelanjutan dan didukung dengan fasilitas - fasilitas terbaik. ${ }^{22}$

\subsection{Strategi Pemasaran Eksternal}

The advantage for Muslim countries in realizing the goal of harmonization is that the idea is not something new to Muslim society. The Islamic teaching has always been about the unity. Unity of mankind is an essential corollary of the fundamental Islamic concept of the Unity of God (Tawhid). If God is one, then mankind is also one.

Strategi pemasaran eksternal atau lingkungan eksternal adalah pengaruh pengaruh tidak langsung yang berada di luar kekuasaan atau kendali pamasar. Pengaruh tersebut akan memaksa pemasar untuk menyesuaikan arah dan strateginya agar tetap bertahan di lingkungannya.

Analisis lingkungan merupakan faktor utama yang menyebabkan terjadinya perubahan -perubahan strategi. Untuk itu perusahaan perlu secara

22 Wawancara dengan Bapak Nuzulkifli, tanggal 07 Juni 2017. 
sistematis menganalisa lingkungan dalam penyusunan strategi menganalisis lingkungan dalam menyusun strategi suatu perusahaan. Hal ini perlu di lakukan karena hasil - hasil yang akan dianalisis akan mendasari pembuatan strategi untuk mencapai tujuan.

Analisis lingkungan industry yang dianggap berpengaruh pada kelangsungan bisnis asuransi pada PT. Prudential Life Assurance Cabang Kota Malang, diantaranya yaitu:

\section{1) Demografis}

Kekuatan demografis utama yang diamati pemasar adalah populasi, karena masyarakat adalah pembentuk pasar. Pemasar sangat tertarik pada ukuran dan tingkat pertumbuhan populasi disuatu kota,wilayah dan negara. ${ }^{23}$

Kekuatan lingkungan yang pertama dimonitor adalah populasi karena orang - orang membentuk pasar. Peningkatan jumlah penduduk Jawa Timur, khususnya Kota Malang perlu diperhatikan oleh pemasar untuk dijadikan pertimbangan dalam rangka memasarkan produknya. Pertumbuhan jumlah penduduk di Kota Malang akan disajikan pada tabel dibawah ini: ${ }^{24}$

Tabel 4.8 Pertumbuhan Jumlah Penduduk Kota Malang Bulan Januari - Juni 2017

\begin{tabular}{|c|l|c|}
\hline No & Bulan & Jumlah \\
\hline 1. & Januari & 895,922 \\
\hline 2. & Februari & 896,977 \\
\hline 3. & Maret & 897,876 \\
\hline 4. & April & 898,810 \\
\hline 5. & Mei & 899,724 \\
\hline 6. & Juni & 900,468 \\
\hline
\end{tabular}

(Sumber : Dinas Kependudukan dan Pencatatan Sipil Kota Malang)

Melihat kondisi demografi Kota Malang diatas, maka kondisi ini merupakan peluang bagi PT. Prudential Life Assurance Cabang Kota Malang. Hal ini disebabkan dengan bertambahnya jumlah penduduk maka kebutuhan masyarakatpun akan bertambah pula dan akan semakin bermacam - macam. Disamping itu, dengan jumlah penduduk yang cukup padat juga memungkinkan perusahaan untuk memperoleh SDM dengan criteria yang telah disesuaikan dengan kebutuhan perusahaan.

\footnotetext{
23 Philip Kotler, Manajemen Pemasaran Edisi 13, (PT. Gelora Aksara Pratama, 2008), hal. 81

${ }^{24}$ Jumlah penduduk Kota Malang diakses pada tanggal 18 Agustus 2017 dari http://dispendukcapil.malangkota.go.id/2017/07/lampid-2017/
} 


\section{2) Ekonomi}

Daya beli yang tersedia dalam ekonomi tergantung pada penghasilan, harga, tabungan, utang dan ketersediaan kredit saat ini. Pemasar harus memperhatikan tren yang mempengaruhi daya beli, karena tren tersebut bisa memberikan pengaruh kuat pada bisnis, terutama untuk perusahaan yang produknya ditujukan kepada konsumen yang berpenghasilan tinggi dan sensitif terhadap harga. ${ }^{25}$

Jumlah penduduk Kota Malang yang semakin meningkat, maka perekonomian warga Kota Malang akan meningkat pula. Meningkatnya perekonomian Kota Malang dapat dilihat dari banyaknya jumlah wisata, dan berbagai macam usaha lainnya seperti kuliner, kerajinan tangan dan lain sebagainya. Dengan meningkatnya perekonomian Kota Malang, maka akan memberikan dampak positif pada PT. Prudential Life Assurance Cabang Kota Malang. Perekonomian masyarakat yang meningkat berarti daya beli masyarakat semakin meningkat pula. Perekonomian yang tinggi memungkinkan pengalokasian pendapatan untuk kebutuhan tersier yang didalamnya adalah kebutuhan untuk berasuransi.

\section{3) Sosial Budaya}

Di dalam menyusun strategi pemasaran, suatu perusahaan harus memperhatikan kondisi sosial budaya masyarakat dimana perusahaan itu beroperasi. Hal ini disebabkanoleh perubahan - perubahan pada kondisi social masyarakat ini dapat mempengaruhi operasi perusahaan dan kebijakan kebijakan perusahaan. Untuk saat ini masyarakat mulai menyadari akan penting mengikuti program asuransi. Hal ini disebabkan oleh tingkat pendidikan masyarakat yang mulai meningkat, sehingga memperngaruhi cara berpikir mereka dalam menentukan sikap, khususnya dalam memutuskan untuk ikut serta dalam program asuransi. Mereka sadar dengan mengikuti program asuransi maka kehidupan mereka pada kehidupan masa yang akan datang akan terjamin lagi.

Meskipun demikian, terdapat sejumlah anggota masyarakat yang mempunyai sikap kurang sadar akan pentingnya asuransi. Untuk itu PT. Prudential Life Assurance Cabang Kota Malang perlu mengadakan hubungan secara langsung maupun tidak langsung di dalam menginformasikan segala sesuatu mengenai tentang produknya. Dalam hal ini PT. Prudential Life Assurance Cabang Kota Malang sendiri telah melakukan kegiatan sehubungan dengan untuk memasyarakatkan asuransi yaitu melakukan kegiatan penyuluhan kepada masyarakat dan menjadi pembicara seminar di instansi lainnya seperti sekolah, kampus dan sebagainya. Berdasarkan dari analisis yang diperoleh maka kondisi sosial budaya mendukung akan pentingnya program asuransi jiwa.

\section{4) Teknologi}

Para pemasar perlu memahami lingkungan teknologi yang berubah dan bagaimana teknologi -teknologi baru dapat dapat memenuhi kebutuhan

\footnotetext{
${ }^{25}$ Ibid, hal. 86.
} 
manusia. ${ }^{26}$ Kemajuan teknologi juga dimanfaatkan oleh PT. Prudential Life Assurance Cabang Kota Malang, salah satunya yaitu pembayaran premi yang bisa dilakukan dimanapun seperti di Bank, ATM, dan Kantor Pos. Selain itu PT. Prudential Life Assurance juga menyediakan Informasi lewat Web yang bisa diakses kapan pun tanpa datang langsung ke kantor PT. Prudential Life Assurance. ${ }^{27}$

\section{5) Politik}

Keputusan pemasaran sangat dipengaruhi oleh perkembangan dalam lingkungan politik. Lingkungan politik terdiri dari hukum dan badan pemerintah atau kelompok yang berpengaruh yang memengaruhi dan membatasi organisasi dan masyarakat. ${ }^{28}$ Pemerintah cukup berpengaruh di dalam menentukan strategi pemasaran suatu perusahaan di sector asuransi jiwa, pemerintah secara berkelanjutan mengupayakan terwujudnya asuransi jiwa yang sehat melalui serangkaian kebijakan dibidang perasuransian. Dalam hal ini perusahaan perlu untuk mempertimbangkan segala kebijakan yang dikeluarkan oleh pemerintah dengan sehubungan dengan kegiatan perasuransian. ${ }^{29}$

Sejauh ini pemerintah telah membuat suatu Undang - Undang Nomor 2 Tahun 1992, serta peraturan pemerintah tentang penyelenggaraan usaha perasuransian, yaitu Peraturan Pemerintah Nomor 63 Tahun1999. Diharapkan dengan adanya kebijakan dari pemerintah tersebut industri perasuransian dapat menerapkan prinsip kehati - hatian dalam melaksanakan usahanya. Berdasarkan penjelasan tersebut maka kondisi pemerintahan juga mendukung perusahaan asuransi dalam meningkatkan pertumbuhan ekonomi.

\section{Kesimpulan}

Setelah menyajikan dan menganalisis data sesuai dengan fokus penelitian, maka peneliti dapat menarik kesimpulan tentang bagaimana Strategi Pemasaran Produk PRUlink Syariah Assurance Account pada PT. Prudential Life Assurance Cabang Kota Malang. Strategi pemasaran yang dilakukan oleh PT. Prudential Life Assurance Cabang Kota Malang dalam memasarkan produk PRUlink Syariah Assurance Account yaitu menggunakan strategi pemasaran internal dan strategi pemasaran ekstenal.

Strategi pemasaran internal merupakan strategi yang dilakukan oleh perusahaan yang berkaitan dengan perusahaan itu sendiri. Artinya perusahaan melakukan perekrutan, pelatihan dan memotivasi para karyawannya terkait dengan komponen 5P yaitu Produk (Product), Harga (Price), Tempat (Place), Promosi (Promotion), dan Orang (People). Strategi pemasaran eksternal atau lingkungan eksternal adalah pengaruh - pengaruh tidak langsung yang berada di luar

\footnotetext{
26 Thamrin Abdullah, Francis Tantri, Manajemen Pemasaran, (Jakarta: PT. Raja Grafindo Persada, 2016), hal. 102.

27 Wawancara dengan Mas Bambang, tanggal 02 Agustus 2017

28 Thamrin Abdullah, Francis Tantri, Manajemen Pemasaran, (Jakarta: PT. Raja Grafindo Persada, 2016), hal. 102.

${ }^{29}$ Wawancara dengan Bapak Nuzulkifli, tanggal 07 Juni 2017
} 
kekuasaan atau kendali pamasar. Pengaruh yang berada diluar kekuasaan atau kendali pemasar tersebut berupa Demografi, Ekonomi, Sosial Budaya, Teknologi dan Politik. Dengan menggunakan strategi pemasaran internal dan ekstermal di lapangan sangat efektif dan efesien, terbukti semakin meningkatnya jumlah nasabah produk PRUlink Syariah Assurance Account pada PT. Prudential Life Assurance Cabang Kota Malang.

\section{Daftar Pustaka}

Ali, Hasan. (2004). Asuransi Dalam Prespektif Hukum Islam Suatu Tujuan, Teori dan Praktis. Jakarta: Kencana.

Assauri, Sofjan. (2004). Manajemen perusahaan. Ed. 1. Jakarta: PT. Raja Grafindo Persada.

Janwari, Yadi. (2005). Asuransi Syariah. Bandung: Pustaka Bani Quraisy.

Jumlah penduduk Kota Malang diakses pada tanggal 18 Agustus 2017 dari http://dispendukcapil.malangkota.go.id/2017/07/lampid-2017/.

Kotler, Philip. (2008) . Manajemen Pemasaran Edisi 13. PT. Gelora Aksara Pratama.

Murti Sumiarti, John Soepriharto. (2000). Pengantar Bisnis. Yogyakarta: Liberty. Nopriansyah, Waldi. (2015). Asuransi Syariah Berkah Terakhir yang Tak Terduga. Yogyakarta: ANDI.

Thamrin Abdullah, Francis Tantri. (2016). Manajemen Pemasaran. Jakarta: PT. Raja Grafindo Persada.

Veithzal, Rifai Zainal, et al. (2017). Islamic Marketing Management. Jakarta: PT. Bumi Aksara. 